\title{
Technology-assisted education in graduate medical education: a review of the literature
}

\author{
Sharhabeel Jwayyed ${ }^{1,2^{*}}$, Kirk A Stiffler ${ }^{1,2}$, Scott T Wilber ${ }^{1,2}$, Alison Southern ${ }^{1,2}$, John Weigand ${ }^{1,2}$, Rudd Bare ${ }^{1,2}$ and
} Lowell W Gerson ${ }^{1,2}$

\begin{abstract}
Studies on computer-aided instruction and web-based learning have left many questions unanswered about the most effective use of technology-assisted education in graduate medical education.

Objective: We conducted a review of the current medical literature to report the techniques, methods, frequency and effectiveness of technology-assisted education in graduate medical education.

Methods: A structured review of MEDLINE articles dealing with "Computer-Assisted Instruction," "Internet or World Wide Web," "Education" and "Medical" limited to articles published between 2002-2007 in the English language was performed. RESULTS: The two literature searches returned 679 articles; 184 met our inclusion and exclusion criteria. In 87 articles, effectiveness was measured primarily using self-reported results from a survey of subjects. Technology-assisted education was superior to traditional methods in 42 of the 64 direct comparison articles (66\%, 95\% Cl 53-77\%). Traditional teaching methods were superior to technology-assisted education in only 3/64 (5\%, 95\% Cl 1-13\%). The remaining 19 direct comparison articles showed no difference. A detailed review of the 64 comparative studies (technology-assisted education versus traditional teaching methods) also failed to identify a best method or best uses for technology-assisted education.

Conclusions: Technology-assisted education is used in graduate medical education across a variety of content areas and participant types. Knowledge gain was the predominant outcome measured. The majority of studies that directly compared knowledge gains in technology-assisted education to traditional teaching methods found technology-assisted education equal or superior to traditional teaching methods, though no "best methods" or "best use" was found within those studies. Only three articles were specific to Emergency Medicine, suggesting further research in our specialty is warranted.
\end{abstract}

Keywords: education, medical, graduate, computer-assisted instruction, Internet or World Wide Web, simulation, virtual reality

\section{Background}

For decades, medical educators have looked for ways to use computer technology to assist education. In the late 1960s, pioneer medical educators began to develop computer systems that laid the foundation for computerassisted instruction in medical education [1,2]. These early systems consisted of drill and practice questions and later basic true-false or matching questions. As computer technology improved, so did computer-

\footnotetext{
* Correspondence: Jwayyeds@summahealth.org

'Department of Emergency Medicine, Summa Akron City Hospital, Akron, $\mathrm{OH}$, USA

Full list of author information is available at the end of the article
}

assisted instruction. Over time, rudimentary computeraided instruction systems were augmented with multimedia laden systems rich with sound, video and animation

The Internet ushered in a new era that allowed for easy distribution of material, easy access by students and central management by administrators $[3,4]$. Technologies such as simulation and virtual reality were developed that added new dimensions to instruction. Today, computer-assisted instruction, web-based education simulation and now virtual reality are some of the technologies frequently used to support graduate

\section{SpringerOpen ${ }^{\circ}$}

(C) 2011 Jwayyed et al; licensee Springer. This is an Open Access article distributed under the terms of the Creative Commons Attribution License (http://creativecommons.org/licenses/by/2.0), which permits unrestricted use, distribution, and reproduction in any medium, provided the original work is properly cited. 
medical education. We refer to these methods as technology-assisted education.

Multiple studies have been performed to evaluate technology-assisted education in medical education. In a 1992 meta-analysis, Cohen et al. found a "medium-sized effect" of computer-assisted instruction on student learning and recommended more research to identify specific features of computer-assisted instruction that lead to improved student performance [5]. In a structured review published in 2002, Chumley-Jones et al. found that webbased learning (WBL) methods can result in student gains but cautioned "...It is a valuable addition to our educational armory, but it does not replace traditional methods....Educators must define WBL's unique educational contribution."[6] In a 2006 structured review, Cook stated that "Research on WBL in medical education has done little to inform practice." [7]

The questions of when, where and how to best use technology-assisted education have not been adequately addressed by the existing literature. As new technologies emerge, new questions continually arise, further complicating matters. Given the cost in time and money associated with the use of many technology-assisted education systems, lack of knowledge on how to best use this technology places educators in a position of dual jeopardy. Valuable resources could be wasted, and potentially more important, ineffective instructional methods could be unintentionally implemented. Emergency Medicine (EM) educators have to navigate these complicated issues when trying to determine the role of technology-assisted education in their curriculum. EM educators, in particular, are hampered by the relative paucity of EM specific studies and must therefore rely on the pool of information present in the general medical education literature. We examined the current technology-assisted education-related medical literature to determine the scope of use of technology-assisted education, whether technology-assisted education improved knowledge when compared with traditional teaching methods, and whether a "Best Method or Best Use" for technology-assisted education could be identified.

Our objectives were to report the techniques, methods and frequency of use of technology-assisted education in graduate medical education, to evaluate the effectiveness of technology-assisted education in improving knowledge compared to traditional and lecture-based teaching methods, and to determine if there was a consensus or general agreement on a "Best Method or Best Use" for technology-assisted education that could be identified.

\section{Materials and methods Design}

We performed a structured review of the medical literature on technology-assisted education.

\section{Search strategies}

Two searches were completed using the National Library of Medicine's PubMed database. The first was performed by the lead author and combined the following keywords using the Boolean search term AND: "Computer-Assisted Instruction," "Internet or World Wide Web," "Education" and "Medical." The search was limited to articles published in the last 5 years in the English language. The 5-year time period was chosen to focus on current teaching method technologies. This search was completed on 30 October 2007 and resulted in 271 citations. The second search was completed by the Information Services librarian using the $\mathrm{MeSH}$ terms ("Education, Medical" OR "Education, Medical, Undergraduate" OR "Education, Medical, Graduate" OR "Education, Medical, Continuing") AND "ComputerAssisted Instruction." This search was limited to studies published in the past 5 years in the English language and performed on 6 December 2007, resulting in 408 citations.

\section{Article selection}

We included all studies that involved graduate medical education and computer-assisted instruction, web-based education, simulation, virtual reality or other technologies. Evaluative articles were defined as those articles that conducted an evaluation of the education effectiveness of the technology or process. We excluded descriptive articles (defined as those that described a technology or process but did not assess its educational effectiveness), as well as dental, veterinary, podiatry and patient education articles.

\section{Article review process}

Two investigators conducted a primary review of each article to determine if they were evaluative or descriptive. A third author resolved discrepancies.

Articles underwent a secondary review to determine the method of assessment used to determine effectiveness and collection of other data elements. Group one articles were defined as those that conducted no comparison between educational methods and determined effectiveness through survey/subject self-report. Group two articles were defined as those that conducted no comparison between educational methods and determined effectiveness using some type of objective before and after measurement. Group three articles were defined as those in which a comparison between educational methods was done and effectiveness was measured using an objective method such as a pretest and posttest, checklist, computer log or direct observation. Articles were also reviewed for any information that suggested a proven or generally accepted best method was used in the study. During secondary review, if 
objective assessment methods were not present, articles were considered descriptive and excluded.

\section{Data collection}

A data collection sheet was developed and pretested on three faculty members who provided feedback on clarity and general usability. Study investigators were then instructed on how to complete the article reviews using the data collection sheet. The five study investigators who performed the article reviews completed a pilot review using the data collection sheet and eight randomly chosen articles from the study sample. The pilot review provided the opportunity to clarify items on the data sheet and article review methods. Feedback from this pilot review was used to further modify the data collection sheet and article review methods.

All articles meeting inclusion criteria were then reviewed by a study investigator and data elements were recorded for each article. If the reviewing investigator had any questions about a data element, the article was reviewed by a panel of investigators consisting of the lead author and two additional investigators. The coding of the data element in question was resolved by the majority opinion of this panel. Data were entered by a research technician into a Microsoft Access database.

\section{Data analysis}

Data were analyzed using $\operatorname{Stata}^{\circledR}$, version 11 . Data are presented using descriptive statistics (means and proportions) with associated 95\% confidence intervals (CI).

\section{Results}

The results of the searches and initial review for eligibility are shown in Figure 1. From the 679 studies originally identified in the searches, 257 articles were excluded because of duplication or failure to meet study criteria in the primary review process. During the secondary review, 238 articles were excluded because of nonobjective assessment methods or not meeting inclusion criteria. A total of 184 studies met the inclusion criteria and were reviewed by an investigator. Descriptive data from these studies are shown in Table 1. Of these, 87 articles were group 1 where no comparison was done between educational methods and effectiveness was measured primarily using self-reported results from a survey of subjects; 18 articles were group 2 where no comparison was done between educational methods and objective before and after methods where used to assess effectiveness. There were 79 articles in group 3 (43\%, 95\% CI 36-50), which consisted of studies in which a comparison was conducted between educational methods and objective methods were used to measure effectiveness (Table 2). Assessment methods commonly used

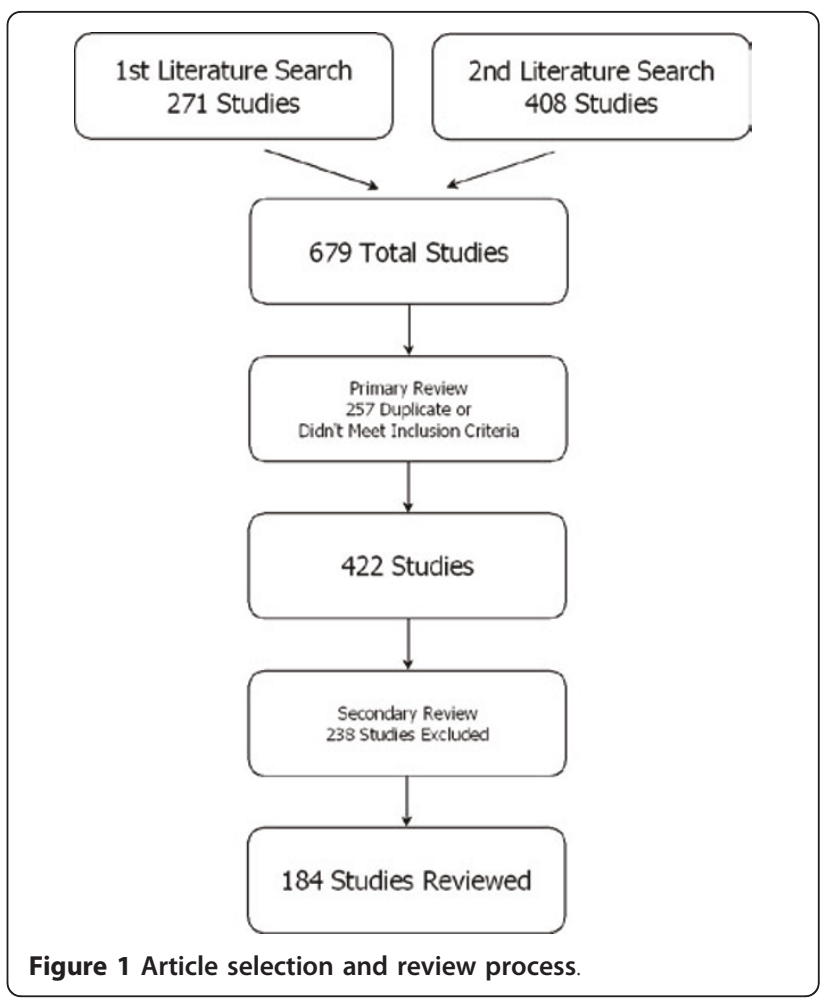

included subject self-assessment by survey, computer log, a pretest and posttest, checklists and direct observation.

In 64 of the group three articles $(64 / 184,35 \%, 95 \%$ CI 28-42), there was a direct comparison between technology-assisted education and traditional teaching methods (Table 3). In the majority of these 64 articles, the subjects were medical students and content area was clinical medicine. Technology-assisted education was superior to traditional teaching methods in 42 of the 64 direct comparison articles (66\%, 95\% CI 53-77\%), traditional teaching methods were superior to technologyassisted education in only 3 of the 64 articles (5\%, 95\% CI 1-13\%), and the remaining 19 showed no difference. No consistent best methods or best uses were identified after review of the articles. A detailed review of the 64 comparative studies (technology-assisted education versus traditional teaching methods also failed to identify a best method or best uses for technology-assisted education.

Most articles evaluated technology-assisted education with regard to clinical medicine $(123 / 184,67 \%, 95 \%$ CI $59-74 \%)$ and basic science education (44/184, 24\%, 95\% CI 18-31\%). Knowledge gains were the most common outcome assessed by the literature (90/184, 49\%, 95\% CI 42-56\%). Other outcomes commonly assessed included satisfaction (82/184, 45\%, 95\% CI 37-52\%), clinical skills (57/184, 31\%, 95\% CI 24-38\%), attitudes (47/184, 26\% 
Table 1 Descriptive study data

\begin{tabular}{|c|c|c|}
\hline & Proportions & $\%(95 \% \mathrm{Cl})$ \\
\hline \multicolumn{3}{|l|}{ Category } \\
\hline Basic science & $45 / 184$ & $24,18-31$ \\
\hline Clinical medicine & $125 / 184$ & $68,61-75$ \\
\hline CME & $6 / 184$ & $3,1-7$ \\
\hline Other & $8 / 184$ & $4,2-8$ \\
\hline \multicolumn{3}{|l|}{ Main outcomes studies assessed } \\
\hline \multicolumn{3}{|l|}{$\begin{array}{l}\text { (Some studies assessed multiple } \\
\text { outcomes) }\end{array}$} \\
\hline Access & $38 / 184$ & $21,15-27$ \\
\hline Attitude & $47 / 184$ & $26,19-32$ \\
\hline Clinical skills & $57 / 184$ & $31,24-38$ \\
\hline Knowledge & $90 / 184$ & $49,41-56$ \\
\hline Satisfaction & $82 / 184$ & $45,37-52$ \\
\hline \multicolumn{3}{|l|}{ Subjects } \\
\hline Attendings & $21 / 184$ & $11,7-17$ \\
\hline Medical students & $111 / 184$ & $60,53-67$ \\
\hline Nursing & $6 / 184$ & $3,1-7$ \\
\hline Residents & $39 / 184$ & $21,15-28$ \\
\hline Combination of subjects & $7 / 184$ & $4,2-8$ \\
\hline \multicolumn{3}{|l|}{ Descriptive study data } \\
\hline \multicolumn{3}{|l|}{ Resident specialty } \\
\hline Emergency medicine & $3 / 39$ & $8,2-21$ \\
\hline Internal medicine & $5 / 39$ & $13,4-27$ \\
\hline General surgery & $10 / 39$ & $26,13-42$ \\
\hline Pediatrics & $6 / 39$ & $15,6-31$ \\
\hline Radiology & $5 / 39$ & $13,4-27$ \\
\hline Other & $3 / 39$ & $8,2-21$ \\
\hline Combination of residents & $7 / 39$ & $18,8-34$ \\
\hline \multicolumn{3}{|l|}{ Technology used } \\
\hline \multirow[t]{2}{*}{ (Some studies used multiple technologies) } & $59 / 184$ & $32,25-39$ \\
\hline & $26 / 184$ & $14,9-20$ \\
\hline CD-ROM/computer based & $16 / 184$ & $9,5-14$ \\
\hline Simulation & $94 / 184$ & $51,44-59$ \\
\hline \multicolumn{3}{|l|}{ Virtual reality } \\
\hline \multicolumn{3}{|l|}{ Web based } \\
\hline \multicolumn{3}{|l|}{ Country of origin } \\
\hline Canada & $12 / 184$ & $6,3-11$ \\
\hline Germany & $18 / 184$ & $10,6-15$ \\
\hline Great Britain & $14 / 184$ & $8,4-12$ \\
\hline United States & $105 / 184$ & $57,50-64$ \\
\hline Others & $35 / 184$ & $16,11-22$ \\
\hline
\end{tabular}

95\% CI 19-32\%) and access to technology-assisted education (38/184, 21\%, 95\% CI 15-27\%). The participants of the studies were predominantly medical students (111/184, 60\%, 95\% CI 53-67\%) and resident physicians (39/184, 21\%, 95\% CI 15-28\%). Of the resident based studies, there was no predominant specialty, with only three studies $(0.02 \%$, 95\% CI $0.003-0.05 \%)$ specific to Emergency Medicine.

\section{Discussion}

Technology-assisted education is used in graduated medical education across a variety of content areas and subject types. Content areas ranged from basic science subjects such anatomy and pathology, to clinical medicine (training in procedures, diagnosis and management), and even to cognitive skills and attitudes [8-13].

Computer and Internet-based methods were the most commonly used modalities followed by simulation and virtual reality. Clinical studies were the most common type of study. The most common study subjects were medical students followed by residents and attending physicians. Only three articles were related to the specialty of emergency medicine. The majority of articles were from authors based in the US and attempted to measure gains in knowledge or skills. Many studies sought to measure satisfaction and attitudes toward the main intervention. The majority of studies that directly compared traditional teaching methods to technologyassisted education found technology-assisted education equal or superior to traditional teaching methods. We did not find any particular method or use of technology-assisted education that could be described as a "Best Method." Assessment methods commonly used included subject self-assessment by survey, computer log, a pretest and posttest, and direct observation.

Technology-assisted education has the potential to enrich learning in ways not possible using traditional methods of instruction [14]. Technology-assisted education allows individualized self-paced learning, improved assessment, evaluation and feedback while increasing learner's exposure to other instructional material $[2,15,16]$. Additionally, technology-assisted education provides for inherent efficiency in the administration of educational material that encompasses development, distribution, retrial, storage and communication. The desire to harness these advantages and the other useful features of technology-assisted education is a driving force behind the efforts of medical educators to determine the most effective use technology-assisted education.

Our study confirms the findings of previous studies that technology-assisted education can result in knowledge improvement $[5,6,17]$. Eighty-seven (87) articles in our study assessed gains by surveying subjects and asking for their self-assessment of improvement in knowledge or skills after exposure to the study method. This may be an inaccurate technique to determine the effectiveness of the teaching method used in the study. Kirkpatrick describes a four-level approach to evaluate training programs. These levels are: Reaction, Learning, Behavior and Results (See Table 4) [18]. A subject's selfreported sense of improvement is likely a measure of the Reaction level and not a true measure of learning. 
Table 2 Description of groups

\begin{tabular}{llll}
\hline Group & Number/Group & Primary method of assessment & Comparison with traditional methods \\
\hline One & 87 & Survey/self-reported results & None \\
Two & 18 & Before/after measurement & None \\
Three & 79 & Objective assessment & Yes \\
& & (pretest/posttest, checklist, etc.) & \\
\hline
\end{tabular}

Student attitude and acceptance of a training method are important precursors to the success of any educational method. However, studies that relied solely on self-assessment to determine the degree of learning may have missed the mark and may be of limited value as a result.

The 64 studies that compared traditional teaching methods with technology-assisted education used objective measurements to determine learning outcomes such as a pretest and posttest, checklist and computer log. Two-thirds found technology-assisted education superior to traditional teaching methods. Why or when technology-assisted education might be better than traditional teaching methods was not always predictable. Visualization has been shown to improve learning [19]. The teaching of subject matter that consists of complex associations or difficult to demonstrate spatial relationships using standard methods can be enhanced with computer-assisted instruction. Some studies we reviewed provide insight on this illusive issue. Thatcher compared the use of computer-assisted instruction to traditional methods to teach medical students about DNA replication and found that the computer-assisted instruction group performed $22 \%$ better on the posttest than the traditional textbook group [20]. Thatcher suggested the multimedia teaching that was possible with computerassisted instruction enriched learning. Computerassisted instruction allowed the complicated sequence of steps and the spatial relationships associated with DNA replication to be presented in a three-dimensional format, something that was not possible with a two-dimensional textbook.

An article we reviewed by Glittenberg and colleagues describes the development and use of a three-dimensional interactive computer-assisted instruction program designed to teach students the basics of the human oculomotor system [21]. This teaching program included information about the main and auxiliary functions of each extra-ocular eye muscle, which eye muscles are active during any given movement of the eye, the path of the oculomotor cranial nerves, the symptoms of cranial nerve paralysis, as well as symptoms of various neurological pathologies. The authors compared this teaching program to standard teaching methods that used textbooks, pictures and diagrams. Formal assessment methods found that the computer-assisted instruction group performed $20 \%$ better than the traditional teaching group. Glittenberg noted that the complex material could be demonstrated in a richer fashion using computer-assisted instruction than was possible with traditional teaching methods and commented that... "These findings suggest that high-quality 3D animations may help students and physicians, especially those with low-spatial abilities, to conceptualize abstract topics in medicine and ophthalmology in a way that makes it easier for them to understand and remember these topics." The conclusions by Thatcher and Glittenberg are supported by Mayer who contends that multimedia learning made possible with technology-assisted education allows information to be presented to the student using multiple sensory pathways [14]. This aids the students' development in understanding the material.

However, improvement in student performance with technology-assisted education was not universal in the studies we reviewed. About a third of studies that compared technology-assisted education with traditional teaching methods found no difference in student performance. Again, it was not always clear why these different teaching methods produced the same results. Corton and colleagues developed an interactive computer-based method to teach pelvic anatomy and compared it to a conventional paper-based teaching method [22]. Study subjects were randomized and pretests, posttests and follow-up tests were used to assess learning. They found no difference in knowledge gains between the technology-assisted education and traditional teaching method group despite that fact that most students preferred the technology-assisted education method. The authors commented that the small number of participants (39) and the fact that many participants had technical difficulty viewing the animations and videos may have impacted the results. In a similar study, Forester examined the effects of four supplemental programs on learning of gross anatomy [23]. The four supplemental programs were student teaching assistance, direct study, weekly instructor review and a web-based anatomy program. There was no significant difference between the interventions as all groups showed improvement in knowledge compared to controls. Given the complex, spatial relationships associated with anatomy, one might have expected the web-based group to outperform the other groups. However, there was no 
Table 364 comparative articles

\begin{tabular}{|c|c|c|c|c|c|c|c|c|c|c|c|}
\hline Author & Category & $\begin{array}{l}\text { Outcomes } \\
\text { measured } \\
A\end{array}$ & $\begin{array}{l}\text { Methods } \\
\text { compared }\end{array}$ & $\begin{array}{c}\text { Study } \\
\text { characteristics } \\
\text { B }\end{array}$ & $\begin{array}{c}\text { Number } \\
\text { of } \\
\text { subjects } \\
\text { in study } \\
\text { C }\end{array}$ & $\begin{array}{c}\text { Study } \\
\text { subjects }\end{array}$ & $\begin{array}{l}\text { Type of } \\
\text { resident C }\end{array}$ & $\begin{array}{c}\text { Magnitude } \\
\text { of benefit \% } \\
\text { D }\end{array}$ & $\begin{array}{c}\text { Type of } \\
\text { assessment } \\
E\end{array}$ & $\begin{array}{l}\text { Preferred } \\
\text { method }\end{array}$ & $\begin{array}{l}\text { Country } \\
\text { of study }\end{array}$ \\
\hline Uranus et al. & $\begin{array}{c}\text { Clinical } \\
\text { medicine }\end{array}$ & $C s, A p$ & VR to Sim & Cs & 62 & $\begin{array}{l}\text { Attendings/med } \\
\text { students }\end{array}$ & NR & "Sig Better" & $\mathrm{DO}$ & Technology-VR & Austria \\
\hline Wehrs & $\begin{array}{l}\text { Clinical } \\
\text { medicine }\end{array}$ & $\mathrm{K}, \mathrm{At}, \mathrm{S}, \mathrm{Ap}$ & Trad to CAl & $C, L$ & 38 & Attendings & $N R$ & 22 & $\mathrm{~T}, \mathrm{~S}$ & Technology & Germany \\
\hline Casebeer & CME & $\mathrm{K}, \mathrm{S}, \mathrm{Ap}, \mathrm{Ac}$ & $\begin{array}{l}\text { Trad to } \\
\text { WBL }\end{array}$ & $C, R$ & 210 & Attendings & $N R$ & 15 & $\mathrm{~T}, \mathrm{~S}$ & Technology & USA \\
\hline Short et al. & CME & K & Trad to CAl & $C, R$ & 52 & Attendings & NR & NRA & S & Standard & USA \\
\hline Butzlaff et al. & $\begin{array}{l}\text { Clinical } \\
\text { medicine }\end{array}$ & $\mathrm{K}, \mathrm{Ap}, \mathrm{Ac}$ & $\begin{array}{l}\text { Trad to } \\
\text { WBL }\end{array}$ & $C, R$ & 72 & Attendings & $N R$ & NA & $\mathrm{T}, \mathrm{S}$ & No difference & Germany \\
\hline Forester et al. & $\begin{array}{c}\text { Basic } \\
\text { science }\end{array}$ & K & $\begin{array}{l}\text { Trad to } \\
\text { WBL }\end{array}$ & $C$ & 477 & Med students & $N R$ & 9 & $\mathrm{~T}, \mathrm{~S}$ & Technology & USA \\
\hline Krippendorf & $\begin{array}{c}\text { Basic } \\
\text { science }\end{array}$ & $\mathrm{K}, \mathrm{S}, \mathrm{Ap}$ & $\begin{array}{c}\text { Trad to CAI/ } \\
\text { VR }\end{array}$ & $\mathrm{C}, \mathrm{Cs}$ & 206 & Med students & NR & 2 & $\mathrm{~T}, \mathrm{~S}$ & Technology & USA \\
\hline Hudson et al. & $\begin{array}{c}\text { Basic } \\
\text { science }\end{array}$ & K & Trad to CAl & $C, R$ & 100 & Med students & $N R$ & 11 & $\mathrm{~T}, \mathrm{~S}$ & Technology & UK \\
\hline Taradi et al. & $\begin{array}{l}\text { Basic } \\
\text { science }\end{array}$ & $\begin{array}{c}\mathrm{K}, \mathrm{At}, \mathrm{S}, \mathrm{Ap} \\
\mathrm{Ac}\end{array}$ & $\begin{array}{l}\text { Trad to } \\
\text { WBL }\end{array}$ & Cs & 220 & Med students & $N R$ & 10 & $\mathrm{~T}, \mathrm{~S}$ & Technology & Croatia \\
\hline Thatcher & $\begin{array}{l}\text { Basic } \\
\text { science }\end{array}$ & $\mathrm{K}, \mathrm{At}, \mathrm{S}, \mathrm{Ap}$ & Trad to CAl & Cs & 22 & Med students & $N R$ & 22 & $\mathrm{~T}, \mathrm{~S}$ & Technology & USA \\
\hline McNulty & $\begin{array}{l}\text { Basic } \\
\text { science }\end{array}$ & K & Trad to CAl & Cs & 130 & Med students & $N R$ & 2 & $\mathrm{~T}, \mathrm{~S}, \mathrm{CL}$ & Technology & USA \\
\hline Noimark et al. & $\begin{array}{l}\text { Clinical } \\
\text { medicine }\end{array}$ & K & $\begin{array}{l}\text { Trad to } \\
\text { WBL }\end{array}$ & Cs & 346 & Med students & $N R$ & 15 & T & Technology & UK \\
\hline Leong et al. & $\begin{array}{l}\text { Clinical } \\
\text { medicine }\end{array}$ & K,S & Trad to CAl & Cs & 379 & Med students & $N R$ & 12 & $\mathrm{~T}, \mathrm{~S}$ & Technology & USA \\
\hline Prinz & $\begin{array}{l}\text { Clinical } \\
\text { medicine }\end{array}$ & K & Trad to CAl & $C, R$ & 172 & Med students & NR & $7 / 16 / 19^{*}$ & $\mathrm{~T}, \mathrm{~S}$ & Technology & Austria \\
\hline Degnan et al. & $\begin{array}{l}\text { Clinical } \\
\text { medicine }\end{array}$ & K & Trad to CAl & $C, R$ & 48 & Med students & $N R$ & NRA & $\mathrm{DO}, \mathrm{CL}$ & Technology & UK \\
\hline Burgess et al. & $\begin{array}{l}\text { Clinical } \\
\text { medicine }\end{array}$ & $\begin{array}{c}\mathrm{K}, \mathrm{At}, \mathrm{S}, \mathrm{Ap} \\
\mathrm{Ac}\end{array}$ & $\begin{array}{l}\text { Trad to } \\
\text { WBL }\end{array}$ & Cs & 91 & Med students & NR & NRA & S & Technology & UK \\
\hline $\begin{array}{l}\text { Vivekananda- } \\
\text { Schmidt et al. }\end{array}$ & $\begin{array}{l}\text { Clinical } \\
\text { medicine }\end{array}$ & $\mathrm{K}, \mathrm{Cs}, \mathrm{At}, \mathrm{S}, \mathrm{Ap}$ & Trad to CAl & $C, R, C S$ & 354 & Med students & $N R$ & "Sig better" & $\mathrm{DO}, \mathrm{S}$ & Technology & UK \\
\hline Callas et al. & $\begin{array}{l}\text { Clinical } \\
\text { medicine }\end{array}$ & S,Ap,Ac & $\begin{array}{l}\text { Trad to } \\
\text { WBL }\end{array}$ & Cs & 903 & Med students & $N R$ & NRA & S & Technology & USA \\
\hline Ganai et al. & $\begin{array}{l}\text { Clinical } \\
\text { Medicine }\end{array}$ & Cs & VR to Trad & $C, R$ & 19 & Med students & $N R$ & 40 & $\mathrm{DO}, \mathrm{T}$ & Technology & USA \\
\hline
\end{tabular}


Table 364 comparative articles (Continued)

\begin{tabular}{|c|c|c|c|c|c|c|c|c|c|c|c|}
\hline Duque et al. & $\begin{array}{c}\text { Clinical } \\
\text { medicine }\end{array}$ & Cs & $\begin{array}{c}\text { Trad to } \\
\text { WBL }\end{array}$ & $\overline{C, L}$ & 100 & Med students & NR & NRA & $\mathrm{T}, \mathrm{S}$ & Technology & Canada \\
\hline Stolz et al. & $\begin{array}{l}\text { Clinical } \\
\text { medicine }\end{array}$ & $\mathrm{K}, \mathrm{S}, \mathrm{Ap}, \mathrm{Ac}$ & $\begin{array}{l}\text { Trad to } \\
\text { WBL }\end{array}$ & - & NR & Med students & $N R$ & 10 & $\mathrm{~T}, \mathrm{~S}$ & Technology & Germany \\
\hline Duque et al. & $\begin{array}{l}\text { Clinical } \\
\text { medicine }\end{array}$ & $\mathrm{Cs}, \mathrm{At}, \mathrm{S}$ & $\begin{array}{l}\text { Trad to } \\
\text { WBL }\end{array}$ & $C, R$ & 133 & Med students & $N R$ & 14 & $\mathrm{~T}, \mathrm{~S}, \mathrm{CKL}$ & Technology & Canada \\
\hline Vash et al. & $\begin{array}{l}\text { Clinical } \\
\text { medicine }\end{array}$ & K & VR to TRAD & $C, R$ & 48 & Med students & $N R$ & NRA & $\mathrm{T}$ & $\begin{array}{c}\text { Technology (in 1/4 } \\
\text { content areas) }\end{array}$ & Iran \\
\hline Schilling et al. & $\begin{array}{l}\text { Clinical } \\
\text { medicine }\end{array}$ & $\mathrm{K}, \mathrm{S}, \mathrm{Ap}$ & $\begin{array}{l}\text { Trad to } \\
\text { WBL }\end{array}$ & $C, R$ & 238 & Med students & $N R$ & $26 / 46^{*}$ & $\mathrm{~T}, \mathrm{~S}$ & Technology & USA \\
\hline Roesch et al. & $\begin{array}{l}\text { Clinical } \\
\text { medicine }\end{array}$ & $\mathrm{K}, \mathrm{S}$ & $\begin{array}{l}\text { Trad to } \\
\text { WBL }\end{array}$ & L & 3050 & Med students & NR & 10 & $\mathrm{~T}, \mathrm{~S}$ & Technology & Germany \\
\hline Ridgway et al. & $\begin{array}{l}\text { Clinical } \\
\text { medicine }\end{array}$ & $\begin{array}{c}\mathrm{K}, \mathrm{S}, \mathrm{Ap}, \mathrm{Ac}, \\
\mathrm{At}\end{array}$ & $\begin{array}{l}\text { Trad to } \\
\text { WBL }\end{array}$ & Cs & 88 & Med students & NR & $4 / 10^{*}$ & $\mathrm{~T}, \mathrm{~S}, \mathrm{CL}$ & Technology & Ireland \\
\hline Qayumi et al. & $\begin{array}{l}\text { Clinical } \\
\text { medicine }\end{array}$ & $\begin{array}{l}\mathrm{K}, \mathrm{S}, \mathrm{Cs}, \mathrm{At} \\
\mathrm{Ap}\end{array}$ & Trad to CAl & $C, R$ & 99 & Med students & NR & $\begin{array}{c}\text { Sig } \\
\text { improvement }\end{array}$ & $\mathrm{T}, \mathrm{S}, \mathrm{DO}$ & Technology & Japan \\
\hline Shokar et al. & $\begin{array}{l}\text { Clinical } \\
\text { medicine }\end{array}$ & $\mathrm{K}, \mathrm{Cs}$ & $\begin{array}{l}\text { Trad to } \\
\text { WBL }\end{array}$ & C & 179 & Med students & $N R$ & $5 / 4^{*}$ & $\mathrm{~T}, \mathrm{DO}$ & Technology & USA \\
\hline Glittenberg et al. & $\begin{array}{l}\text { Clinical } \\
\text { medicine }\end{array}$ & $\mathrm{K}, \mathrm{At}, \mathrm{S}$ & Trad to CAl & $C, R$ & 140 & Med students & $N R$ & 17 & $\mathrm{~T}, \mathrm{~S}$ & Technology & Austria \\
\hline Friedl et al. & $\begin{array}{l}\text { Clinical } \\
\text { medicine }\end{array}$ & $\mathrm{K}, \mathrm{Cs}$ & Trad to CAl & C & 195 & Med students & Surg & $\begin{array}{l}\text { 15/18 Cs } \\
\text { only }\end{array}$ & $\mathrm{T}, \mathrm{DO}$ & $\begin{array}{c}\text { Standard (no diff K, CAl } \\
>>\text { Cs) }\end{array}$ & Germany \\
\hline Engum et al. & $\begin{array}{l}\text { Clinical } \\
\text { medicine }\end{array}$ & $\mathrm{K}, \mathrm{Cs}, \mathrm{S}$ & Trad to VR & $C, R$ & 163 & Med students & $N R$ & NRA & $\mathrm{T}, \mathrm{S}, \mathrm{CKL}$ & Standard & USA \\
\hline Hariri et al. & $\begin{array}{l}\text { Basic } \\
\text { science }\end{array}$ & $\mathrm{K}, \mathrm{S}$ & Sim to Trad & $C, R$ & 29 & Med students & NR & NA & $\mathrm{T}, \mathrm{S}$ & No difference & USA \\
\hline Kumar et al. & $\begin{array}{c}\text { Basic } \\
\text { science }\end{array}$ & $\begin{array}{c}\mathrm{K}, \mathrm{At}, \mathrm{S}, \mathrm{Ap} \\
\mathrm{Ac}\end{array}$ & Trad to CAl & $\mathrm{Cs}$ & 212 & Med students & $N R$ & NRA & S & Technology & Australia \\
\hline Cox et al. & $\begin{array}{l}\text { Clinical } \\
\text { medicine }\end{array}$ & $\mathrm{K}, \mathrm{At}, \mathrm{S}$ & $\begin{array}{l}\text { Trad to } \\
\text { WBL }\end{array}$ & $C, R$ & 100 & Med students & $N R$ & NA & $\mathrm{T}, \mathrm{S}$ & No difference & USA \\
\hline Chou et al. & $\begin{array}{l}\text { Clinical } \\
\text { medicine }\end{array}$ & K & VR to Trad & $C, R$ & 16 & Med students & NR & NA & $C K L$ & No difference & USA \\
\hline Hahne et al. & $\begin{array}{l}\text { Clinical } \\
\text { medicine }\end{array}$ & $\mathrm{K}, \mathrm{At}, \mathrm{S}$ & Trad to CAl & $C, R$ & 167 & Med students & $N R$ & NA & $\mathrm{T}, \mathrm{S}$ & No difference & Germany \\
\hline Curran et al. & $\begin{array}{l}\text { Clinical } \\
\text { medicine }\end{array}$ & $\mathrm{K}, \mathrm{Cs}, \mathrm{At}, \mathrm{S}$ & Sim to Trad & $C, R$ & 60 & Med students & NR & NA & $\mathrm{T}, \mathrm{S}, \mathrm{CKL}$ & No difference & Canada \\
\hline Wahlgren et al. & $\begin{array}{l}\text { Clinical } \\
\text { medicine }\end{array}$ & $\begin{array}{c}\mathrm{K}, \mathrm{At}, \mathrm{S}, \mathrm{Ap} \\
\mathrm{Ac}\end{array}$ & Trad to CAl & $C, R, L$ & 116 & Med students & NR & NA & $\mathrm{T}, \mathrm{S}, \mathrm{CL}$ & No difference & Sweden \\
\hline Raij et al. & $\begin{array}{l}\text { Clinical } \\
\text { medicine }\end{array}$ & $C s, A p$ & VR to Trad & C & 82 & Med students & NR & NA & $\mathrm{S}, \mathrm{CL}$ & No difference & USA \\
\hline Nackman et al. & $\begin{array}{l}\text { Clinical } \\
\text { medicine }\end{array}$ & Cs & $\begin{array}{l}\text { Trad to } \\
\text { WBL }\end{array}$ & Cs & 198 & Med students & NR & NA & T & No difference & USA \\
\hline
\end{tabular}


Table 364 comparative articles (Continued)

\begin{tabular}{|c|c|c|c|c|c|c|c|c|c|c|c|}
\hline Karnath et al. & $\begin{array}{l}\text { Clinical } \\
\text { medicine }\end{array}$ & Cs & Trad to CAl & $C, R$ & 192 & Med students & NR & NA & $\mathrm{T}$ & No difference & USA \\
\hline Feeg et al. & $\begin{array}{l}\text { Clinical } \\
\text { medicine }\end{array}$ & $\mathrm{K}, \mathrm{At}$ & Trad to CAl & $C, R$ & 125 & Nurses & NR & 10 & $\mathrm{~T}$ & Technology & USA \\
\hline Anderson et al. & $\begin{array}{l}\text { Clinical } \\
\text { medicine }\end{array}$ & $\mathrm{K}, \mathrm{Cs}$ & $\begin{array}{l}\text { Trad to } \\
\text { WBL }\end{array}$ & Cs & 180 & Nurses & NR & NA & S & No difference & USA \\
\hline Dee et al. & $\begin{array}{l}\text { Basic } \\
\text { science }\end{array}$ & K & Trad to CAl & $L$ & 98 & Other & NR & NRA & $\mathrm{S}$ & Technology & USA \\
\hline Errichetti et al. & $\begin{array}{l}\text { Clinical } \\
\text { medicine }\end{array}$ & Cs & Trad to CAl & $C, R$ & 40 & Med students & NR & NRA & $\mathrm{CL}$ & Technology & USA \\
\hline Ryan et al. & $\begin{array}{l}\text { Basic } \\
\text { science }\end{array}$ & K & Trad to CAl & C & 23 & Med students & NR & NA & S & No difference & Ireland \\
\hline Gold et al. & $\begin{array}{l}\text { Basic } \\
\text { science }\end{array}$ & $\mathrm{K}, \mathrm{S}$ & Trad to CAl & $C, R$ & 138 & Residents & Surg & NRA & $\mathrm{T}, \mathrm{S}, \mathrm{CL}$ & Technology & USA \\
\hline Roche et al. & $\begin{array}{c}\text { Basic } \\
\text { science }\end{array}$ & K & Trad to CAl & $C, R$ & 38 & Residents & Peds & 11 & $\mathrm{~T}, \mathrm{~S}$ & Technology & USA \\
\hline Gold et al. & $\begin{array}{l}\text { Basic } \\
\text { ccience }\end{array}$ & $\mathrm{K}, \mathrm{S}$ & Trad to CAl & $C, R$ & 138 & Residents & Surg & NRA & $\mathrm{T}, \mathrm{S}, \mathrm{CL}$ & Technology & USA \\
\hline Barsuck et al. & $\begin{array}{l}\text { Clinical } \\
\text { medicine }\end{array}$ & $\mathrm{K}, \mathrm{Cs}$ & Sim to Trad & Cs & 72 & Residents & NR & $47 / 31^{*}$ & $\mathrm{~T}, \mathrm{CL}$ & Technology & Israel \\
\hline Xiao et al. & $\begin{array}{l}\text { Clinical } \\
\text { medicine }\end{array}$ & $\mathrm{K}, \mathrm{CS}$ & $\begin{array}{c}\text { Trad to CAl/ } \\
\text { WBL }\end{array}$ & $C, R, C s$ & 50 & Residents & EM/Surg & 41 & $C L$ & Technology & USA \\
\hline Knoll et al. & $\begin{array}{l}\text { Clinical } \\
\text { medicine }\end{array}$ & Cs & Sim to Trad & $C, R$ & 30 & $\begin{array}{l}\text { Residents/ } \\
\text { attendings }\end{array}$ & GU & NRA & $\mathrm{CL}, \mathrm{CKL}$ & Technology & Germany \\
\hline Mahnke et al. & $\begin{array}{l}\text { Clinical } \\
\text { medicine }\end{array}$ & Cs & Trad to CAl & Cs & 40 & Residents & Peds & 21 & $\mathrm{~T}$ & Technology & USA \\
\hline Park et al. & $\begin{array}{l}\text { Clinical } \\
\text { medicine }\end{array}$ & Cs & Sim to Trad & $C, R$ & 24 & Residents & IM/Surg & NRA & $\mathrm{CL}, \mathrm{CKL}$ & Technology & Canada \\
\hline Schijven et al. & $\begin{array}{l}\text { Clinical } \\
\text { medicine }\end{array}$ & $\mathrm{K}, \mathrm{S}, \mathrm{Ap}$ & VR to Trad & C & 24 & Residents & Surg & NRA & $\mathrm{DO}, \mathrm{S}$ & Technology & Netherlands \\
\hline Maiss et al. & $\begin{array}{l}\text { Clinical } \\
\text { medicine }\end{array}$ & Cs & $\begin{array}{l}\text { Sim to } \\
\text { Other }\end{array}$ & $C, R$ & 35 & Residents & IM & NRA & $\mathrm{CL}$ & Technology & France \\
\hline Jonas et al. & $\begin{array}{l}\text { Clinical } \\
\text { medicine }\end{array}$ & Cs & Sim to Trad & $C, R$ & 14 & $\begin{array}{l}\text { Residents/med } \\
\text { students }\end{array}$ & Ophthal & NRA & $\mathrm{CKL}$ & Technology & Germany \\
\hline Sedlack et al. & $\begin{array}{l}\text { Clinical } \\
\text { medicine }\end{array}$ & Cs & Sim to Trad & C & 38 & Residents & IM & NRA & $\mathrm{S}, \mathrm{CKL}$ & Technology & USA \\
\hline Corton et al. & $\begin{array}{c}\text { Basic } \\
\text { science }\end{array}$ & $\mathrm{K}, \mathrm{S}, \mathrm{Ap}$ & Trad to CAl & $\mathrm{C}, \mathrm{R}, \mathrm{L}$ & 39 & Residents & GYN & NA & $\mathrm{T}, \mathrm{S}$ & No difference & USA \\
\hline Jowett et al. & $\begin{array}{l}\text { Clinical } \\
\text { medicine }\end{array}$ & Cs & Trad to CAl & $C, R, L$ & 30 & Residents & Surg & NA & $\mathrm{T}$ & No difference & Canada \\
\hline Chung et al. & $\begin{array}{l}\text { Clinical } \\
\text { medicine }\end{array}$ & K & $\begin{array}{l}\text { Trad to } \\
\text { WBL }\end{array}$ & $C, R, L$ & 63 & Residents & EM & NA & $\mathrm{T}, \mathrm{S}, \mathrm{CL}$ & No difference & USA \\
\hline
\end{tabular}


Table 364 comparative articles (Continued)

\begin{tabular}{|c|c|c|c|c|c|c|c|c|c|c|c|}
\hline Davis et al. & $\begin{array}{l}\text { Clinical } \\
\text { medicine }\end{array}$ & $\mathrm{K}, \mathrm{At}$ & Trad to CAl & $C, R$ & 55 & Residents & NR residents & NA & $\mathrm{T}, \mathrm{S}$ & No difference & UK \\
\hline Ferguson et al. & $\begin{array}{l}\text { Clinical } \\
\text { medicine }\end{array}$ & K & $\begin{array}{c}\text { Trad to } \\
\text { WBL }\end{array}$ & $\mathrm{O}$ & 19 & Residents & Surg & NA & $\mathrm{T}, \mathrm{CL}$ & No difference & USA \\
\hline Bridgemohan et al. & $\begin{array}{l}\text { Clinical } \\
\text { medicine }\end{array}$ & $\mathrm{K}, \mathrm{At}, \mathrm{S}$ & Trad to CAl & $\mathrm{R}$ & 46 & Residents & Peds & NA & $\mathrm{T}, \mathrm{S}$ & No difference & USA \\
\hline
\end{tabular}

Legend: outcomes measured $A$

Ac: Access (can students get to and use the learning material); Ap:Applicability (can you teach with this method); At: Attitude; Cs: Clinical Skills (e.g.: H+P skills, EKG, CXR interpretation); Cs: Cost; K: Knowledge retention/ learning: O: Other; S: Satisfaction.

Legend: study characteristics $B$

C: Controlled (there was a control group); Cs: Cross sectional (single point in time); L: Longitudinal (more than one point in time); O: Other; R: Random (randomization of groups.)

Legend: number of subjects in study/type of resident $C$

NR: Not reported

Legend: magnitude of benefit \% $D$

NRA: Not readily available; NA: Not applicable; *Multiple measurements

Legend: type of assessment $E$

DO: Direct observation; T: Test; S: Survey; CL: Computer log; CKL: Check list. 
Table 4 Kirkpatrick's four levels of evaluation

\begin{tabular}{|c|c|c|}
\hline Level & Focus of level & Possible measurement method \\
\hline Reaction & $\begin{array}{l}\text { Student's perception of or satisfaction with training } \\
\text { method }\end{array}$ & Survey, focus groups \\
\hline Learning & $\begin{array}{l}\text { To measure if students' knowledge/skills/attitude } \\
\text { changed }\end{array}$ & $\begin{array}{l}\text { Control group } \\
\text { Objective pretest/post test of knowledge/skills } \\
\text { Direct observation Checklist }\end{array}$ \\
\hline Behavior & $\begin{array}{l}\text { Determine if the new knowledge/skills/attitudes are } \\
\text { being used by the student }\end{array}$ & $\begin{array}{l}\text { Control group } \\
\text { Direct observation checklist } \\
\text { Before/after interview or survey of student's direct contacts or supervisors }\end{array}$ \\
\hline Results & The trainings impact on the organization & $\begin{array}{l}\text { An improvement in quality, productivity, reduction in cost, increase profit or some } \\
\text { other tangible benefit to the organization }\end{array}$ \\
\hline
\end{tabular}

Adapted from Kirkpatrick [18]

explanation advanced as to why all four groups performed the same. Interestingly, students in this study preferred the method that provided more direct contact with the instructors.

Other investigators in our review, such as Davis et al., who conducted a study on teaching evidence-based medicine, and Cox et al., who studied teaching concepts related to the underserved, found no difference between technology-assisted education and traditional teaching methods, suggest that technology-assisted education methods could serve as a possible alternative to lecture $[24,25]$. These authors note the potential savings in time related to student/instructor travel and preparation of content as well as the ability to standardize content and teaching methods $[24,25]$. An additional advantage of the technology-assisted education methods is that these methods can be made available continuously for use when convenient to the students. Whether "no difference" means that instructional methods are interchangeable is an open question that is probably best determined by further study.

We were unable to identify specific information in the articles we reviewed that lead us to a "Best Method or Best Use" for technology-assisted education. We had hoped that the 64 studies that directly compared technology-assisted education to traditional education methods would provide information regarding this question. In many of these reviewed studies, authors offered opinions similar to those advanced by Thatcher and Glittenberg within their papers. Additional light is shed on the issue by other investigators. Cook et al. published an article that reviews ten steps to effective web-based learning [26]. Issenberg and colleagues, in a systemic review of simulation-based education, identified 20 important guidelines they recommend authors should adhere to when conducting research on simulation-based education [27]. The efforts of these authors provide more pieces to the puzzle that help bring the answer to the question of how best to use technology-assisted education into better focus.
When motion pictures were first invented, Thomas Edison is reported to have predicted that motion pictures would revolutionize education. Experts agree it did not [14]. Similar unfulfilled claims were made when other technologies like radio and television were invented [14]. We certainly should not repeat the mistakes of our predecessors. Our study found that technology-assisted education is used across the wide spectrum of graduate medical education underscoring the reality that technology-assisted education is here to stay and will likely change teaching and learning in ways we cannot predict. Consider the experience of Piemme, who in a 1988 article expressed excitement at the potential uses of a new technology called the CD-ROM [1].

Despite a body of research that suggests technologyassisted education can improve knowledge gains and student achievement, there remains difficulty in establishing technology-assisted education's exact role in the current curriculum and the degree to which it can replace traditional teaching methods $[5-7,15,28]$. Rapidly evolving computer technology presents educators with potential new methods of instruction on a near continuous basis $[1,29,30]$. This is one factor that makes it difficult to determine the best use of technology-assisted education. An additional confounder may be faulty use of technology-assisted education by educators. We have been constantly reminded that technology-assisted education is a tool that needs to be used properly if it is to be effective. Educators should seek resources that explain how to effectively use technology-assisted education before investing time and money on its application (see Additional readings) [26,27,31-34].

Another barrier to determining technology-assisted education's role in the curriculum is the quality of the published research in this domain. Our study is similar to other studies that showed conflicting results when technology-assisted education methods were compared to traditional methods $[6,17]$. In the studies we reviewed, there was a wide variety of subjects, settings 
and assessment methods. Many investigators have voiced concerns about the persistent limitations, often systemic, that exist in studies on computer-based education $[5-7,17,35]$. Some authors have suggested that studies that compare traditional non-computer teaching methods to computer-based learning are fundamentally flawed because no true comparison exists between the two [36,37]. Friedman and Cook suggest it would be more productive to study one form of technologyassisted education versus another or study how to effectively integrate and measure technology-assisted education's impact on learning [36,37].

We had difficulty identifying the core elements in many of the studies we reviewed (see Limitations). Concordant with this finding, a number of authors have recommended a more organized and programmatic approach to research in the area of technology-assisted education (and medical education in general) to advance our understanding in this domain [36-39]. Detailed information about all aspects of the study as well as specific goals and objectives combined with formal, valid assessment methods are critical precursors for an effective study.

Medical educators are tasked with teaching competencies established by the Accreditation Council of Graduate Medical Education (ACGME). These competencies have been described elsewhere [40]. We would recommend authors align their research with the ACGME core competencies and identify which core competencies are being addressed by the study. Competency can be defined as the specific knowledge, skill and attitude needed to complete a task correctly. Authors should identify which aspect of competency their study deals with (knowledge, skill or attitude) and precisely how the competency is measured. A more organized approach to technologyassisted education research may allow educators across specialties to learn from each other. This could facilitate a more comprehensive cross-specialty understanding of how to best use technology-assisted education. If, for example, researchers in the surgical specialties identified key training elements of technology-assisted education need to master the skills of laparoscopic procedures, these training elements might be important in learning other skills such as endotracheal intubation or lumbar puncture. Similarly, if one specialty identified the key training elements of professionalism that could be taught or measured using technology-assisted education, all specialties would benefit from this knowledge. More structured, programmatic research maybe the best way to foster transfer of training knowledge from one specialty to another and may be the only way to identify a "Best Method or Best Use" for technology-assisted education, something that has eluded medical educators for decades.

\section{Limitations}

Our study has a number of limitations. We attempted to conduct a review of the medical literature covering a 5year period. The sensitivity of literature searches varies and can be improved when conducted by librarians [41]. Despite using the services of experienced research librarians for our search, some articles may not have been identified and therefore are not included in the body of literature.

The wide variety of study designs, settings, subjects, assessment and reporting methods made combining results impossible. This heterogeneity of outcomes precluded a meta-analysis from being performed [42]. Additionally, reporting methods used in some studies made data abstraction difficult. In some studies, it was difficult to determine core elements such as who the subjects were because of vague descriptions and incomplete definitions. Despite the use of a study panel to resolve disagreements associated with data abstraction, errors could have been made. Additionally, we did not independently evaluate the original author's results as this was beyond the scope of our review.

\section{Conclusions}

Technology-assisted education is used in graduate medical education across a variety of content areas and subject types. Studies in our review show technologyassisted education can result in improvements in knowledge. Sixty-seven percent (67\%) of studies that directly compared knowledge gains in technology-assisted education to traditional teaching methods found technology-assisted education equal or superior to traditional teaching methods. Only three articles dealt primarily with EM. This suggests further research in our specialty is warranted. We would recommended EM educators follow programmatic research methods to avoid limitations found in other studies and consider aligning their research with the ACGME core competencies.

\section{Article Summary Key Questions}

Why is the topic important?

Technology-assisted education is widely used in graduate medical education. Technology-assisted education needs to be used correctly if it is to be effective. Otherwise, valuable training time and resources could be wasted.

\section{What does this study attempt to show?}

Our study attempted to determine the scope of use of technology-assisted education, whether technology-assisted education improved knowledge when compared with traditional teaching methods, and 
whether a "Best Method or Best Use" for technology-assisted education could be identified.

\section{What are the key findings?}

-Technology-assisted education can improve knowledge. However, use of technology-assisted education does not guarantee knowledge gains as approximately one third of studies did not show improvement in knowledge gains.

-Many articles in our study (87) assessed gains by surveying subjects and asking for their self-assessment of improvement in knowledge or skills after exposure to the study method. This may be an inaccurate technique to determine the effectiveness of the teaching method used.

- Despite years of use and multiple studies, a "Best Method" or "Best Use" of technology-assisted education was not found.

- Only three articles dealt primarily with Emergency Medicine. This suggests further research in our specialty is warranted. We would recommended EM educators follow programmatic research methods to avoid limitations found in other studies and consider aligning their research with the ACGME core competencies.

\section{How is patient care impacted?}

Improvements in instructional methods should result in enhanced competency by physician thereby improving patient care.

\section{Acknowledgements}

Special thanks to Heather Holmes and Kim Sweeney of Summa Akron City Hospital Information Services for their help with the literature search. Presentation

Presented at the CORD Academic Assembly, March 5-7, 2009, Las Vegas, NV

\section{Author details}

'Department of Emergency Medicine, Summa Akron City Hospital, Akron, $\mathrm{OH}$, USA ${ }^{2}$ Northeastern Ohio Medical University, Rootstown, OH, USA

\section{Authors' contributions}

All authors have made substantial contributions to the intellectual content of the paper. SJ, KAS, STW contributed to the conception and design, acquisition of data, analysis and interpretation of data, statistical analysis, drafting of the manuscript, critical revision of the manuscript for important intellectual content. AS, JW, RB contributed the acquisition of data, analysis and interpretation of data, administrative and technical support. LWG contributed to the conception and design, drafting of the manuscript and supervision.

\section{Competing interests}

The authors declare that they have no competing interests.

Received: 31 March 2011 Accepted: 8 August 2011

Published: 8 August 2011
References

1. Piemme TE: Computer-assisted learning and evaluation in medicine. The Journal of American Medical Association 1988, 260(3):367-372.

2. Dev P, Hoffer EP, Barnett GO: Computers in Medical Education. In Biomedical Informatics.. 3 edition. Edited by: Shortliffe E, Cimino JJ. New York, NY: Springer Science and Business Media, LLC; 2006:737.

3. Computer communication for international collaboration in education in public health: The TEMPUS Consortium for a New Public Health in Hungary. Ann N Y Acad Sci 1992, 670:43-49.

4. Ellaway RH: E-learning and e-teaching. In A Practical Guide for Medical Teachers.. 3 edition. Edited by: Dent JA, Harden RM. New York, NY Elsevier Churchhill Livingston; 2009:229.

5. Cohen PA, Dacanay LS: Computer-based instruction and health professions education, a meta-analysis of outcomes. Evaluation and The Health Professions 1992, 15(3):259-281

6. Chumley-Jones HS, Dobbie A, Alford CL: Web-based learning: sound educational method or hype? A review of the evaluation literature. Acad Med 2002, 77(10 Suppl):S86-93.

7. Cook DA: Where are we with Web-based learning in medical education. MedicalTeacher 2006, 28(7):594-598.

8. Giani U, Brascio G, Bruzzese D, Garzillo C, Vigilante S: Emotional and cognitive information processing in web-based medical education. $J$ Biomed Inform 2007, 40(3):332-342.

9. Glaser AY, Hall CB, Uribe JIS, Fried MP: Medical students' attitudes toward the use of an endoscopic sinus surgery simulator as a training tool. American Journal of Rhinology 2006, 20:177-179.

10. Lang EV, Sood A, Anderson B, Kettenmann E, Armstrong E: Interpersonal and communication skills training for radiology trainees using a rotating peer supervision model (microteaching). Acad Radiol 2005, 901-908.

11. Lapshin OM, Wasserman E, Finkelstein J: Computer intervention to decrease level of psychiatric stigma among medical students. AMIA Symposium Proceedings 2006, 998.

12. Link TM, Marz R: Computer literacy and attitudes towards e-learning among first year medical students. BMC Med Educ 2006, 6:34.

13. McNulty JA, Halama J, Esiritu B: Evaluation of computer-aided instruction in the medical gross anatomy Curriculum. Clinical Anatomy 2004, 17:73-78.

14. Mayer RE: The Promise of Multimedia Learning. Multimedia Learning. 2 edition. New York, New York: Cambridge University Press; 2009, 3.

15. Valdez G, McNabb M, Foertsch M, Anderson M, Hawkes M, Raack L: Computer-Based Technology and Learning: Evolving Uses and Expectations. Revised Edition. North Central Regional Educational Laboratory 2000.

16. Clayden GS, Wilson B: Computer-assisted learning in medical education. Med Educ 1988, 22(5):456-467.

17. Letterie GS: Medical education as a science: the quality of evidence for computer-assisted instruction. Am J Obstet Gynecol 2003, 188(3):849-853.

18. Kirkpatrick DL, Kirkpatrick JD: Evaluation Training Programs, the four levels. 3 edition. San Francisco: Berrett-Koehler Publishers, Inc; 2006, 21-70.

19. Baker R, Dwyer F: A meta-analytic assessment of the effect of visualized instruction. Int J Instr Media 2000, 27:417-426.

20. Thatcher JD: Computer animation and improved student comprehension of basic science concepts. J Am Osteopath Assoc 2006, 106(1):9-14.

21. Glittenberg C, Binder S: Using 3D computer simulations to enhance ophthalmic training. Ophthal Physiol Opt 2006, 26:40-49.

22. Corton MM, Mclntire DD, Wai CY, Ling FW, Wendel GD: A comparison of an interactive computer-based method with a conventional reading approach for learning pelvic anatomy. Am J Obstet Gynecol 2006, 195(5):1438-1443.

23. Forester JP, Thomas PP, McWhorter DL: Effects of four supplemental instruction programs on students' learning of gross anatomy. Clin Anat 2004, 17(4):322-327.

24. Davis J, Chryssafidou E, Zamora J, Davies D, Khan K, Coomarasamy A: Computer-based teaching is as good as face to face lecture-based teaching of evidence based medicine: a randomised controlled trial. BMC Med Educ 2007, 7:23.

25. Cox ED, Koscik RL, Olson CA, Behrmann AT, Hambrecht MA, McIntosh GC, Kokotailo PK: Caring for the underserved: blending service learning and a web-based curriculum. Am J Prev Med 2006, 31(4):342-349.

26. Cook DA, Dupras DM: A practical guide to developing effective webbased learning. J Gen Intern Med 2004, 19(6):698-707. 
27. Issenberg SB, McGaghie WC, Petrusa ER, Gordon DL, Scalese RJ: Features and uses of high-fidelity medical simulations that lead to effective learning: a BEME systematic review. Med Teach 2005, 27(1):10-28.

28. Niemiec R, Walberg HJ: Comparative effects of computer-assisted instruction: a synthesis of reviews. J Educational Computer Research 1987, 3(1).

29. Friedman CP: Coping with innovation frenzy. Acad Med 1994, 69(3):194-195.

30. Henry JB: Computers in medical education: information and knowledge management, understanding, and learning. Hum Pathol 1990, 21(10):998-1002.

31. Dent JA, Harden RM: A Practical Guide for Medical Teachers. 3 edition. New York, NY: Elsevier Churchill Livingston; 2009.

32. Mayer RE: The Promise of Multimedia Learning. Multimedia Learning. 2 edition. New York, New York: Cambridge University Press; 2009.

33. Shortliffe E, Cimino Jj: Computers in Medical Education Biomedical Informatics. New York, NY: Springer Science and Business Media, LLC; 2006.

34. Simonson M, Smaldino S, Albright M, Zvacek S: Teaching and Learning at a Distance Foundations of Distance Education. 4 edition. Boston: Pearson Education, Inc; 2009 .

35. Adler MD, Johnson KB: Quantifying the literature of computer-aided instruction in medical education. Acad Med 2000, 75(10):1025-1028.

36. Friedman CP: The research we should be doing. Acad Med 1994, 69(6):455-457.

37. Cook DA: The Research we still are not doing: an agenda for the study of computer-based learning. Acad Med 2005, 80(6):541-548.

38. Lurie SJ: Raising the passing grade for studies of medical education. JAMA 2003, 290(9):1210-1212.

39. Regehr G: Trends in medical education research. Acad Med 2004, 79(10):939-947.

40. Accreditation Council of Graduate Medical Education: ACGME Outcome Project. 2010 [http://www.acgme.org/Outcome/], Accessed April 15.

41. McKibbon KA, Haynes RB, Dilks CJW, Ramsden MF, Ryan NC, Baker L, et al: How good are clinical MEDLINE searches? A comparative study of clinical end-user and librarian searches. Computers and Biomedical Research 1990, 23(6):583-593.

42. Egger M, Smith GD, Phillips AN: Meta-analysis:Principles and Procedures. British Medical Journal 1997, 315(7121):1533-7.

doi:10.1186/1865-1380-4-51

Cite this article as: Jwayyed et al:. Technology-assisted education in graduate medical education: a review of the literature. International Journal of Emergency Medicine 2011 4:51.

\section{Submit your manuscript to a SpringerOpen ${ }^{\circ}$ journal and benefit from:}

- Convenient online submission

- Rigorous peer review

- Immediate publication on acceptance

- Open access: articles freely available online

- High visibility within the field

- Retaining the copyright to your article

Submit your next manuscript at $\gg$ springeropen.com 